\title{
Territory size of three Antbirds (Aves, Passeriformes) in an Atlantic Forest fragment in southeastern Brazil
}

\author{
Charles Duca ${ }^{1,2}$; Tadeu J. Guerra ${ }^{1} \&$ Miguel Â. Marini ${ }^{1,2}$ \\ ${ }^{1}$ Departamento de Biologia Geral, Instituto de Ciências Biológicas, Universidade Federal de Minas Gerais. Caixa Postal 486, \\ 30161-970 Belo Horizonte, Minas Gerais, Brasil. E-mail: frugivoros@hotmail.com \\ ${ }^{2}$ Departamento de Zoologia, Instituto de Biologia, Universidade de Brasília. 70910-900 Brasília, Distrito Federal, Brasil. \\ E-mail: chduca@ig.com.br; marini@unb.br
}

\begin{abstract}
Territory size is an important ecological attribute of populations that has been considered a factor determines population density. Antbirds is a large group of mainly insectivorous Neotropical passerines, usually well represented in bird communities from forested landscapes in Neotropical region. Territory sizes for three Antbirds, Thamnophilus caerulescens (Vieillot, 1816) (Variable Antshrike), Dysithamnus mentalis (Temmink, 1823) (Plain Antvireo) e Pyriglena leucoptera (Vieillot, 1818) (White-shouldered Fire-eye), were mapped and their area estimated by the convex polygon method in a 50 ha forest fragment, in southeastern Brazil. The three species presented small territories of similar sizes ( $\leq 2$ ha) both during the non-reproductive and the reproductive seasons of 2000-2001. Territories overlapped considerably among species but not intraspecifically. Territory sizes increased with body mass of the three species studied ( $P$. leucoptera $>T$. caerulescens $>D$. mentalis). We failed to find any effect on territory size for the three species associated with forest edge or distance to the dirt road.
\end{abstract}

KEY WORDS. Dysithamnus mentalis; Thamnophilidae; Pyriglena leucoptera; territoriality; Thamnophilus caerulescens.

RESUMO. Tamanho de território de três espécies de Thamnophilidae (Aves, Passeriformes) em um fragmento de Mata Atlântica no sudeste do Brasil. O tamanho do território é um importante atributo ecológico das populações, sendo considerado um fator que pode determinar densidades populacionais. Os Thamnophilidae formam um grupo diverso de pássaros insetívoros, usualmente representativos nas comunidades de aves em florestas da região Neotropical. Neste estudo estimamos o tamanho de território de três espécies de Thamnophilidae, Thamnophilus caerulescens (Vieillot, 1816) (Choca-da-mata), Dysithamnus mentalis (Temmink, 1823) (Choquinha-lisa) e Pyriglena leucoptera (Vieillot, 1818) (Papa-taoca-do-sul), através do método de polígono convexo, em um fragmento de Mata Atlântica no sudeste do Brasil. Os territórios foram pequenos ( $\leq 2$ ha) para as três espécies e não variaram significativamente entre as estações não reprodutiva e reprodutiva. Os territórios sobrepuseram-se consideravelmente entre as três espécies, mas não em cada espécie. $O$ tamanho dos territórios aumentou com a massa corporal das três espécies ( $P$. leucoptera $>T$. caerulescens $>D$. mentalis). Não foi observada nenhuma relação entre o tamanho do território e sua distância à borda da mata e à estrada para as três espécies.

PALAVRAS-CHAVE. Dysithamnus mentalis; Thamnophilidae; Pyriglena leucoptera, territorialidade; Thamnophilus caerulescens.

Territory size is an important ecological attribute of populations because it may determine population density and affect the local distribution and abundance of both intruders and prey (CAPENTER 1987). The adaptive value of territorial behavior has been related to the defense of resources and reproductive success (DAviES 1978). However, this theme remains a topic for discussion (Møller 1990, Rodrigues 1998), once the factors underlying territoriality are not the same for all species (VERNER 1977).

The benefit of territoriality relies in owners having either more a particular resource or better resources than they would have otherwise. According to Perrins \& Birkhead (1983), the main resources that birds may defend in territories include food, nesting sites and mates. In a comparative study, SCHOENER (1968), considering birds defending territories where the main resource was food, found that territory size was directly related to the bird's body weight. In the tropics, the predominant territorial system is year-round defense of feeding and nesting territories (STUTChbuRy \& Morton 2001). Year-round territoriality is typical of tropical insectivorous birds (BUSKIRK 1976) and arthropod resources are defensible because they are more or less evenly distributed spatially and temporally (STUTCHвuRY \& Morton 2001). However, territory size may change over the season independently of food abundance.

Revista Brasileira de Zoologia 23 (3): 692-698, setembro, 2006 
Thamnophilidae is a diverse group in South America and is restricted to the Neotropical region (SICK 1997). Most Thamnophilidae are narrowly associated to the subcanopy or to certain distinct formations in the forest (RIDLEY \& TUDOR 1994, STOTZ et al. 1996, SICK 1997) and are affected by forest fragmentation (Willis 1979, BierregaArd et al. 1992, Sieving \& Karr 1997). Whereas some species of the family are quite sensitive to forest fragmentation, others apparently derive benefit from it (R. RiвON pers. comm.). Three species, Thamnophilus caerulescens (Vieillot, 1816) (Variable antshrike), Dysithamnus mentalis (Temmink, 1823) (Plain antvireo) and Pyriglena leucoptera (Vieillot, 1818) (White-shouldered fire-eye), were considered in the present study. These species are predominantly insectivorous (DURÃEs $\&$ MARINI 2005) and react differentially to forest fragmentation (R. Ribon pers. comm.). Our goals were to determine territory size for these three species, evaluating spatial variations in parameters of the territories between the non-reproductive and reproductive seasons. We also evaluated if the distance to the forest edge and a dirt road affect territory size.

\section{MATERIAL AND METHODS}

\section{Study area}

We conducted this study in a 50 ha forest fragment located at the "Área de Proteção para fins de Preservação do Manancial do Barreiro" (from here on, Barreiro) $\left(20^{\circ} 00^{\prime} \mathrm{S}\right.$, $43^{\circ} 59^{\prime}$ W), in Belo Horizonte, Minas Gerais state, southeastern Brazil. This forest fragment is at the transition zone between the Cerrado and the Atlantic Forest domains (Veloso 1966, RizzinI 1979). The region has a strongly marked climatic regime, with a well defined rainy season between October and March and a dry season lasting from April to September. Barreiro is a 2,000 ha reserve, dominated by open cerrado, but also containing forest fragments of $1,1.7,50$, and 200 ha. The vegetation of the studied fragment ( $50 \mathrm{ha}$ ) is a seasonal mesophilous forest preserved for about 150 years. There is evidence that the forest has been much more developed in the past at least in part of its extent (CEтEC 1993). The fragment is cut by a $5 \mathrm{~m}$ wide dirt road of restricted use by security and researchers. Trees along the road formed a partial canopy connecting the forest long the two sides of the road, although the road itself was kept open. A 19.3 ha grid was established in the forest fragment with long, narrow trails marked at $50 \mathrm{~m}$ intervals, forming $50 \mathrm{~m} \times 50 \mathrm{~m}$ squares. This grid included edge and forest interior areas.

\section{Data collection}

We captured birds monthly with mist nets at 12 lines in the four forest fragments of the Barreiro. Within the 50 ha fragment, birds were captured from 1995 through 2000 at four mist-net lines being three of them inside the observation grid. Some individuals were attracted to nets with their song playback. Birds were marked with metallic bands provided by CEMAVE (IBAMA) and unique combinations of three plastic color bands.
Observations were conducted with binoculars, mostly between 05:00 and 14:00, from March to August 2000 (nonreproductive season) and from September 2000 to February 2001 (reproductive season). Observations were conducted inside the grid in 5 minutes stops at every $50 \mathrm{~m}$ at trail intersections. Singing individuals had their color bands identified, and were followed until disappearing. The area of the grid where each individual was observed was plotted on a map and their territory was recorded until their size ceased to increase. When P. leucoptera was observed following ant swarm (Labidus sp.), the movement was not considered to demarcation its territory.

Territory was mapped and its area measured by the convex polygon method (ODum \& Kuenzler 1955), which consists in joining the outermost observation points for each bird with a straight line. The largest polygon obtained was taken as the bird territory size. Although this method has been subjected to criticism (WORTON 1987), it was chosen due to its simplicity and wide use in ornithology (e.g. Jullien \& Thiollay 1998, Wiktander et al. 2001, Ribeiro et al. 2002). The smallest perpendicular distances from the center of each territory to the forest edge and to the dirt road were obtained with a $50 \mathrm{~m}$ tape.

\section{Statistical analyses}

Differences in territory size among species were tested with a one-way analysis of variance (ANOVA) for each season. For $T$. caerulescens and P. leucoptera, paired t-tests were used to evaluate the differences in territory sizes and distances of the territory centers to the forest edge and to the road between the non-reproductive and reproductive seasons. For D. mentalis, whose number of territory owners in both seasons was very small we used a t-test for independent samples. To evaluate if territory sizes were affected by the distance to forest edge or the road we used multiple regressions, using the data collected for each species in each season. All statistical analyses followed ZAR (1984).

\section{RESULTS}

\section{Territory size}

The difference in territory size among the three species in the non-reproductive season was just marginally not significant $\left(\mathrm{F}_{2,14}=3.47, \mathrm{p}<0.06\right)$ being, on average, the territory size of $P$. leucoptera $>$ T. caerulescens $>$ D. mentalis (Tab. I, Figs 1-2). In the reproductive season, the difference was significant $\left(\mathrm{F}_{2,15}=19.57\right.$, $\mathrm{p}<0.001)$. A planned comparison showed significant differences between the territory size of $P$. leucoptera and of the other two species that had smaller territories (both, $\mathrm{F}_{1,15}=37.70, \mathrm{p}<0.001$ ). Differences were marginally significant when compared the territory size of $T$. caerulescens and D. mentalis $\left(\mathrm{F}_{1,15}=4.18, \mathrm{p}<0.058\right)$. There were no significant differences in the territory size between seasons for the three species (Tab. II).

\section{Territory stability}

A male (3) and two pairs (2 and 8) of T. caerulescens that held territories in the non-reproductive season were not observed in the reproductive season. However, another two pairs 

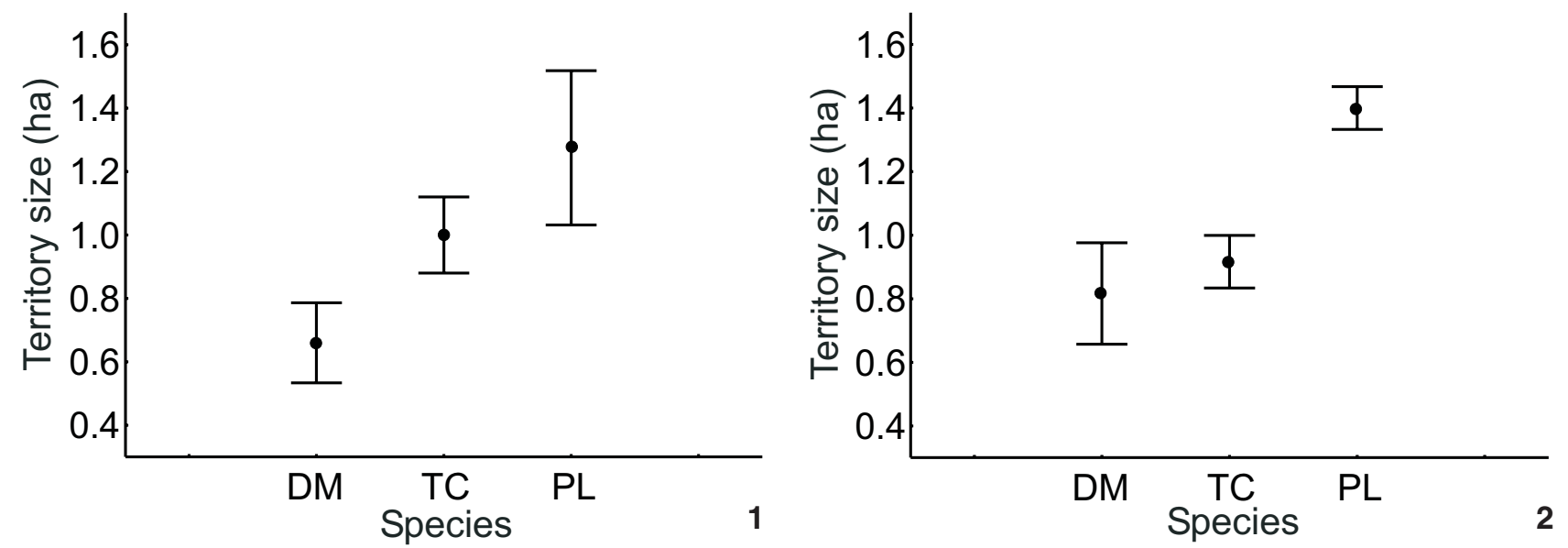

Figures 1-2. Territory sizes in the non-reproductive (1) and reproductive (2) seasons of Dysithamnus mentalis (DM), Thamnophilus caerulescens (TC), and Pyriglena leucoptera (PL) at a forest fragment in southeastern Brazil. Middle points and whiskers represent mean and standard error, respectively.

Table I. Territories spatial parameters in the non-reproductive and reproductive seasons. (N) Number of the territory assess; (D) density of pairs; (PS) pairing success of the territory owners (\%); (MAX) maximum value; (M $\pm E S$ ) mean \pm standard error; (MIN) minimum value. * The mean value of the $D$. mentalis territory size was obtained excluding one territory considered outlier in the sample (1.6 ha), being the mean including this territory equal to $0.8 \pm 0.2$ ha.

\begin{tabular}{|c|c|c|c|c|c|c|c|c|c|c|c|c|}
\hline \multirow{2}{*}{ Species } & \multirow{2}{*}{$\mathrm{N}$} & \multirow{2}{*}{$\mathrm{D}$} & \multirow{2}{*}{ PS } & \multicolumn{3}{|c|}{ Territory size (ha) } & \multicolumn{3}{|c|}{ Edge distance $(\mathrm{m})$} & \multicolumn{3}{|c|}{ Road distance $(\mathrm{m})$} \\
\hline & & & & MAX & $M \pm S E$ & MIN & MAX & $M \pm S E$ & MIN & MAX & $M \pm S E$ & MIN \\
\hline \multicolumn{13}{|l|}{ Non-reproductive season } \\
\hline Thamnophilus caerulescens & 8 & 0.41 & 100 & 1.5 & $1.0 \pm 0.3$ & 0.6 & 225 & $118 \pm 76$ & 25 & 142 & $77 \pm 40$ & 37 \\
\hline Dysithamnus mentalis & 5 & 0.26 & 100 & 1.0 & $0.7 \pm 0.2$ & 0.3 & 240 & $129 \pm 69$ & 75 & 175 & $80 \pm 67$ & 4 \\
\hline Pyriglena leucoptera & 4 & 0.20 & 100 & 2.0 & $1.3 \pm 0.6$ & 0.8 & 117 & $66 \pm 46$ & 27 & 150 & $59 \pm 64$ & 0 \\
\hline \multicolumn{13}{|l|}{ Reproductive season } \\
\hline Thamnophilus caerulescens & 9 & 0.41 & 88.9 & 1.2 & $0.9 \pm 0.2$ & 0.6 & 325 & $150 \pm 101$ & 40 & 220 & $124 \pm 65$ & 0 \\
\hline Dysithamnus mentalis* & 5 & 0.31 & 83.3 & 0.8 & $0.7 \pm 0.1$ & 0.4 & 340 & $147 \pm 120$ & 50 & 220 & $135 \pm 52$ & 90 \\
\hline Pyriglena leucoptera & 4 & 0.20 & 100 & 1.6 & $1.4 \pm 0.1$ & 1.3 & 360 & $202 \pm 46$ & 75 & 130 & $101 \pm 37$ & 50 \\
\hline
\end{tabular}

Table II. Comparative Student t-test between non-reproductive and reproductive seasons. Significance level: $\mathrm{p} \leq 0.05 ;{ }^{*}$ Student $\mathrm{t}$-test for independent samples.

\begin{tabular}{|c|c|c|c|c|c|c|c|c|c|}
\hline \multirow{2}{*}{ Species } & \multicolumn{3}{|c|}{ Territory size } & \multicolumn{3}{|c|}{ Edge distance } & \multicolumn{3}{|c|}{ Road distance } \\
\hline & $\mathrm{t}$ & df & p & $\mathrm{t}$ & df & $p$ & $\mathrm{t}$ & df & p \\
\hline Thamnophilus caerulescens & 0.07 & 5 & 0.94 & -0.49 & 5 & 0.64 & -44.5 & 5 & 0.07 \\
\hline Dysithamnus mentalis* & 0.00 & 8 & 1.00 & -0.39 & 8 & 0.70 & -1.68 & 8 & 0.13 \\
\hline Pyriglena leucoptera & -0.50 & 3 & 0.65 & -2.06 & 3 & 0.13 & -1.91 & 3 & 0.15 \\
\hline
\end{tabular}

(10 and 11) and an unpaired male (12) established territories in the area (Fig. 3). The territory of individual-3 was poorly sampled and was not considered in the analyses. Of the five $D$. mentalis pairs monitored during the non-reproductive season, three pairs (1, 2 and 5) maintained their territories. Three new pairs (6, 8 and 9) and an unpaired male (7) established new territories in the reproductive season (Fig. 4). Pairs 3 and 4, observed in the non-reproductive season, were not observed in the reproductive season. The territory of pair 2 was poorly sampled in the reproductive season, and was not considered in the analyses of this period. All P. leucoptera pairs maintained their territories in both seasons (Fig. 5). 


\section{Population density}

In both seasons $T$. caerulescens was the species that presented the highest density, while $P$. leucoptera was the species with lowest density. A small increase in density was observed only for $D$. mentalis in the reproductive season. Interspecific overlapping territories were evident, but intraspecific overlapping territories were not observed for the three species. Analyzing each species separately, territories were spaced and non-overlapping (Figs 3-5).

\section{Pairing success}

The four pairs of $P$. leucoptera were paired in both seasons. For T. caerulescens and D. mentalis, one territory owner of each species did not pair successfully in the reproductive season (individuals 12 and 7, respectively) (Tab. I, Figs 3-4).

\section{Edge and road effect}

The distances to the forest edge and the road were very variable and no significant differences were detected between seasons, only a difference marginally significant from the distance of T. caerulescens territories to the road (Tab. II). However, territory distances to the forest edge and the road were larger in the reproductive season for the three species (Tab. I). For P. leucoptera territories, the minimum distances in relation to the forest edge and the road increased 50-m in the reproductive season. Seemingly, the distance to the forest edge and the road did not affect the territory size (Tab. III).

\section{DISCUSSION}

According to HINDE (1956), for species that defend territories within which all activities, such as mating, nesting and foraging occur, the importance of food in such territories is illustrated by the marked relationship between territory size and bird size. Therefore, a positive correlation between territory size and body mass is expected for species with similar diets (PerRINs \& BIRKHEAD 1983). The average territories size seems to be directly related to the average body mass of the three species studied here, since D. mentalis has smaller body mass (12.2 g) and smaller territory (0.7 ha), P. leucoptera has larger body mass (26.5 g) and larger territory (1.3 ha) and T. caerulescens present intermediate values of body mass (20.6 g) and territory size (1.0 ha). In the Amazon Forest, woodpeckers (Picidae) are larger and defend larger territories, while woodcreepers (Dendrocolaptidae) have smaller body mass and territories (Terborgh et al. 1990). These authors reported that the difference between territories of gleaners and snatchers seems best accounted for by their considerably smaller mean size. Therefore, our data and the Terborgh's data for Amazonian Forest confirm the conclusions of the HINDE (1956) and Perrins \& Birkhead (1983).

The territory size of P. leucoptera, T. caerulescens and D. mentalis are relatively small in relation to Amazonian birds. In Amazonian Forest the mean territory sizes for all insectivores was 14 ha and only considering Thamnophilidae (body mass $\leq 30 \mathrm{~g}$ ) the mean territory size was 6.1 ha (Terborgh et al.
1990). Moreover, in the Amazonian Forest Thamnophilidae with smaller body mass than the ones we studied have larger territories (Terborgh et al. 1990). The territory size of six species of Thamnophilidae in Atlantic Forest varied from 0.8 to 3.0 ha (Willis \& ONIKI 2001). These authors found territory sizes for $P$. leucoptera (2-3 ha) relatively larger than the one we found, and $D$. mentalis territory size $(0.8 \mathrm{ha})$ was similar to the one we established. In spite of Oniki's data, our data, Willis \& Oniki's and Mendonça \& Gonzaga's data indicate that Thamnophilidae territories, in areas of Atlantic Forest, are smaller than the ones of similar species living in the Amazonian forest.

All the avian species for which the size of reproductive territory has been studied in relation to the nesting cycle show temporal changes in territory size (MølLer 1990). The methodology used in this study did not allow us to determine changes in the territory size during the reproductive cycle. However, our data indicates that for three species in the study area, the territory size did not vary between non-breeding and breeding seasons. The variation in the territory size can be related to food abundance (BURKER \& Nol 1998), varying among different forest types and during the breeding season (STENGER \& FaLLS 1959) resulted of the territorial behavior and the trade-off between energy and predation risk (WiKTANDER et al. 2001). In spite of variations in territory size registered for some species, Stutchiury \& MorTon (2001) consider that in the tropics yearlong territory defense is common and adult survival high, so breeding vacancies may be scarce. Multi-species territoriality of understory birds from Neotropical forest suggests a high yearlong stability of both limits and home ranges areas (JulLien \& Thiollay 1998). Despite the strong seasonal variation in food abundance, territory sizes of Basileuterus flaveolus (Bair, 1865) (Emberizidae) did not vary between seasons (Duca \& MARINI 2005). Therefore, our data corroborate the hypothesis that tropical insectivorous birds defend year-round territories.

Although turnover of territory owners have been observed for $T$. caerulescens and D. mentalis between seasons, the characteristics of the territories did not present significant differences. Greenberg \& Gradwohl (1986), reported that despite a moderate turnover of territory owners, territories of other Thamnophilidae were essentially identical from year to year. The turnover of territory owners also was observed for $T$. caerulescens (WILLIS \& ONIKI 2001) and B. flaveolus without change in the territories characteristics (DuCA \& MARINI 2005). Several studies have found that territory switching occurs at a low rate in year-round residents (Greenberg \& Gradwohl 1986, 1997, WoOdWorth et al. 1999).

The absence of intraspecific overlapping territories and the pattern of territory distribution of T. caerulescens, D. mentalis and P. leucoptera characterize a territorial system for the three species. Territorial intrusions were not common in our study, with just a record of $P$. leucoptera following an ant swarm. According to WiLlis \& ONIKI (1988), some Antbirds associated with ant swarm enter in the neighboring territory. In a study con- 

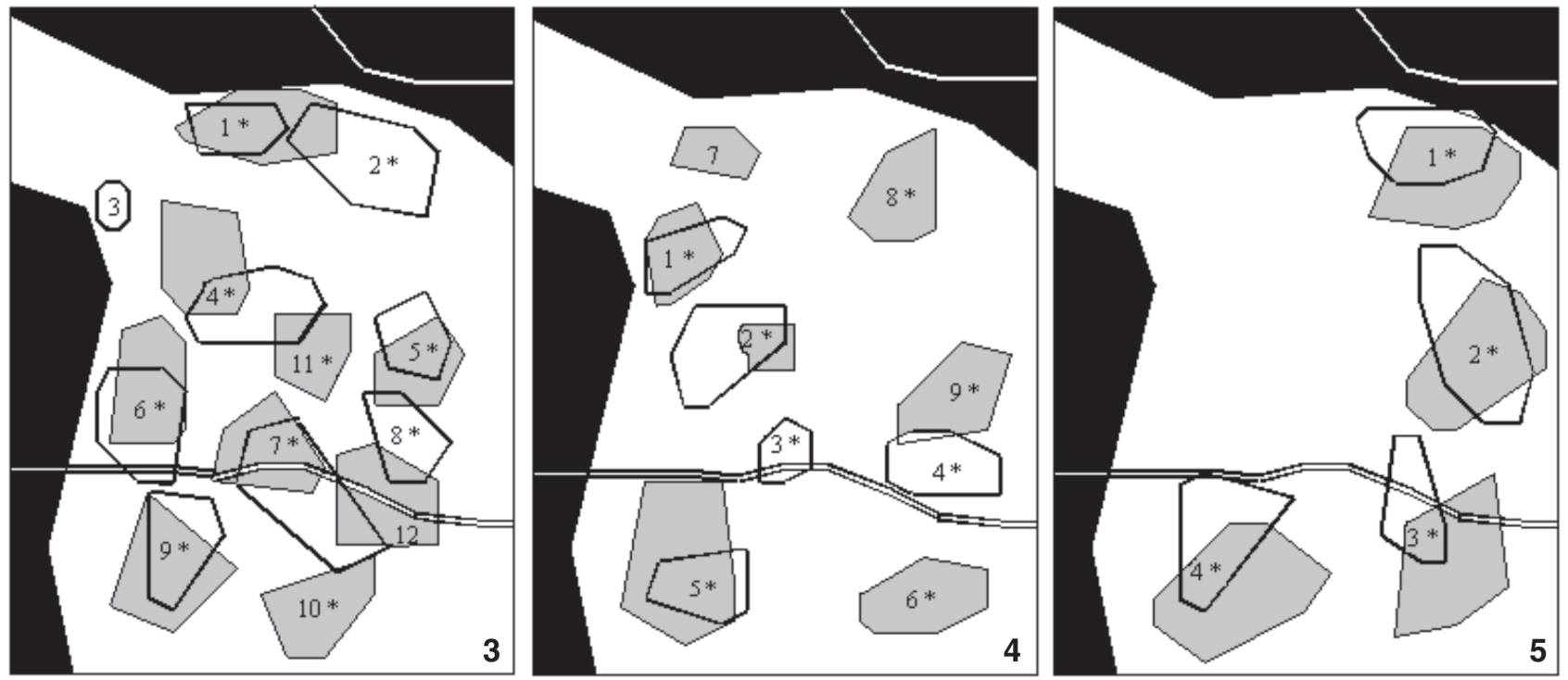

Figures 3-5. Distribution of territories in the non-reproductive (solid line polygons) and reproductive (shaded polygons) seasons of Thamnophilus caerulescens (3), Dysithamnus mentalis (4) and Pyriglena leucoptera (5) at a forest fragment in southeastern Brazil. Numbers indicate territory owner and numbers followed by an asterisk indicate mated individuals. (White) Forest, (Black) Cerrado (Savanna), $(=)$ Dirt road.

Table III. Multiple regressions between territory size and territory distances to the border and road. Significance level: $p \leq 0.05$.

\begin{tabular}{|c|c|c|c|c|c|c|c|c|}
\hline \multirow{2}{*}{ Species } & \multicolumn{4}{|c|}{ Non-reproductive } & \multicolumn{4}{|c|}{ Reproductive } \\
\hline & $\mathrm{N}$ & $\mathrm{R}^{2}$ & $\mathrm{~F}$ & $\mathrm{p}$ & $\mathrm{N}$ & $\mathrm{R}^{2}$ & $\mathrm{~F}$ & $\mathrm{p}$ \\
\hline Thamnophilus caerulescens & 8 & 0.14 & 1.25 & 0.31 & 8 & 0.18 & 0.67 & 0.54 \\
\hline Dysithamnus mentalis & 5 & 0.70 & 2.33 & 0.29 & 6 & 0.19 & 0.24 & 0.80 \\
\hline Pyriglena leucoptera & 4 & 0.68 & 1.10 & 0.55 & 4 & 0.43 & 0.36 & 0.75 \\
\hline
\end{tabular}

ducted in the same study area, B. flaveolus also had non-overlapping territories (DUCA \& Marini 2005). Nevertheless, $B$. flaveolus and the three species territories considered here presented great overlapping, indicating that these four species did not have interspecific territoriality in study area. Robinson \& Terborgh (1995) documented interspecific territoriality in 10 of 12 species of passerines in Peru Amazon most without overlapping territories. Some of the same species did not have interspecific territoriality elsewhere (STOUFFER 1997).

The three species studied here presented stable populations between seasons. The number of pairs of T. caerulescens and $P$. leucoptera in the study site showed no seasonal variation and $D$. mentalis showed an insignificant variation. Most insectivorous understory birds do not differ significantly in abundance, despite demonstrating differences in food availability (Wright 1979). Greenberg \& Gradwohl (1986) observed no change in the density of other Thamnophilidae between the first year and subsequent years. These authors suggest that these breeding populations are socially regulated at a constant level below the limits directly set by food supply. The pair density of the three species considered here was similar to the other Atlantic Forest Thamnophilidae of similar size (e.g. WILLIS \& ONIKI 2001). These authors found P. leucoptera pair density of 0.3 pair/ ha similar to the one found here $(0.2 \mathrm{pair} / \mathrm{ha})$.

Although the factors that determine the territory size are more complex (PARKER 1974, Møller 1990), the territoriality can determine the population density, and species with larger territories would tend to present in smaller densities (CARPENTER 1987). The inverse relation between territory size and population density has been demonstrated for other passerines (MORSE 1976, Yamagishi \& UedA 1986). Considering the territories size of the species that we studied, the expected pair densities would be $D$. mentalis, T. caerulescens and P. leucoptera, in crescent order. This was somehow observed in our data, since P. leucoptera defended larger territories and occurs in lower density $(0.20$ pair/ha), while $D$. mentalis defended smaller territories and had higher density (0.31 pair/ha). An inversion of that relationship is observed when we compared D. mentalis and $T$. caerulescens, which have higher density ( 0.41 pair/ha) and larger territory size than $D$. mentalis. This can be explained by the

Revista Brasileira de Zoologia 23 (3): 692-698, setembro, 2006 
fact that $D$. mentalis is more sensitive to the fragmentation effects than $T$. caerulescens, being significantly affected by the forest size (R. Riвon pers. comm.). Analyzing the distribution maps of the territories, we found that $P$. leucoptera and D. mentalis did not occupy the entire available habitat. It might indicate that density could not be the main reason affecting the territory size of these species in the studied forest fragment, which could be affecting the territory size of only T. caerulescens. Thus, D. mentalis was more sensitive to the fragmentation than P. leucoptera (R. Ribon pers. comm.), what could explain the absence of these species on the available habitat in the forest fragment. WiLLIs (1979) suggest that P. leucoptera disappears from fragments smaller than 50 ha, but ANJos (2001) recorded this species in forest fragments four times smaller. Even so, the low density of P. leucoptera and D. mentalis indicate vulnerability to local extinction of these two species. As T. caerulescens used the whole available habitat it is likely that the density exerts effect in the regulation of the territory size of this species.

We did not find any relationship between the distances to the forest edge nor the road with the territory sizes and pairing success for the three species observed. Due to our small sample size, however we cannot make safe conclusions. However, it is possible that the edge effect exerts role in the determination of the territories, especially for $D$. mentalis, which is considered a species sensitive to fragmentation (R. RibON pers. comm.) and less frequently closer to borders and in second-growth woodland (Ridgely \& Tudor 1994). The lack of relationship between the distance to the forest edge and the territory sizes for $T$. caerulescens and P. leucoptera, agree with the habit of these two species, being common at forest borders (Ridgely \& Tudor 1994). Basileuterus flaveolus territory sizes were not influenced by the forest border but males defending territories close to edges had higher pairing success (DUCA \& MARINI 2005). In contrast, males of Seiurus aurocapillus (Linnaeus, 1766) (Emberizidae) have low pairing success when defending territories close to forest edges (GibBs \& FAABORG 1990). Willis \& ONIKI (2001) suggest that birds that defend territories in the border need larger areas, because they cannot move in all directions to find food, but it does not seem to be the pattern for B. flaveolus (DUCA \& MARINI 2005) and for the three species studied here.

Considering the restricted use of the road in the study area, it was expected that the disturbances from the road would be small. Our results did not present a significant effect of the road in territory sizes and location of the three studied species. However, the marginally significant differences between the distance of T. caerulescens territories to the road, and the average increase in the distances from territory centers to the road for the three species in the reproductive season, suggest some adverse effects of the road that were not detected here. In another study of the road effects on understory mixed-species flocks in the Amazon, three of five flocks were restricted to just one side of the road, but two other flocks had territories that spanned the roads (Develey \& Stouffer 2001). In the same study, the authors reported that the roads (without canopy liking the two sides) formed territorial limits for the five flocks living in the area. Thus, our results suggest that road effect in our study area is minimum or, at least, restricted to the cleared area.

\section{ACKNOWLEDGMENTS}

To the administrators of COPASA (Companhia de Saneamento de Minas Gerais) for following us access to their reserve; C. Galdino, P. Marco-Jr. and J.B. Pinho, M. Anciães, T.M. Aguilar, and anonymous reviewer. The results of this study are part of the project: "Efeitos espaciais e temporais da fragmentação de habitats sobre espécies de aves e insetos: subsídios para o manejo e conservação de florestas - MMA/PROBIO". CNPq, GEF, BIRD provided financial support. C. Duca had a fellowship from CNPq/DTI and M.Â. Marini had a research fellowship from CNPq.

\section{REFERENCES}

Anjos, L. Dos. 2001. Bird communities in five Atlantic forest fragments in southern Brazil. Ornitologia Neotropical, Québec, 12: 11-27.

Bierregaard, R.O. Jr.; T.E. Lovejov; V. Kapos; A.A. dos Santos \& R.W. Hutchings. 1992. The biological dynamics of tropical rainforest fragments. Bioscience, New York, 42: 859-866.

BurKer, D.M. \& E. Nol. 1998. Influence of food abundance, nestsite habitat, and forest fragmentation on breeding Ovenbirds. The Auk, Lawrence, 115 (1): 96-104.

Buskirk, W.H. 1976. Social systems in a tropical forest avifauna. The American Naturalist, Chicago, 110: 293-310.

Carpenter, F.L. 1987. The study of territoriality: Complexities and future directions. The American Zoologist, Washington, 27: 401-409.

CETEC. 1993. Desenvolvimento de metodologia para a recuperação do revestimento florístico natural em áreas de proteção das captações de água da COPASA na Região metropolitana da grande Belo Horizonte. Belo Horizonte, SAT/CETEC, 83p.

DAvies, N.B. 1978. Ecological questions about territorial behaviour, p. 317-350. In: J.R. KREBS \& N.B. DAVIES (Eds). Behavioral ecology: an evolutionary approach. Oxford, Blackwell Scientific Publications, 494p.

Develey, P.F. \& P.C. Stouffer. 2001. Effects of roads on movements by understory birds in mixed-species flocks in central Amazonian Brazil. Conservation Biology, Malden, 15 (5): 1416-1422.

DucA, C. \& M.Â. Marini. 2005. Territory size of the Flavescent Warbler, Basileuterus flaveolus (Passeriformes, Emberizidae), in a forest fragment in Southeastern Brazil. Lundiana, Belo Horizonte, 6 (1): 29-33.

DuRÃEs, R. \& M.Â. MARINI. 2005. A quantitative assessment of birds diets in the Brazilian Atlantic Forest, with recommendations for future diet studies. Ornitologia Neotropical, Québec, 16: 65-83. 
Gibbs, J.P. \& J. FaAborg. 1990. Estimating the viability of Ovenbirds and Kentucky warbler populations in forest fragments. Conservation Biology, Malden, 4: 193-196.

Greenberg, R. \& J. Gradwohl. 1986. Constant density and stable territoriality in some tropical insectivorous birds. Oecologia, Berlin, 69: 618-625.

Greenberg, R. \& J. Gradwohl. 1997. Territoriality, adult survival, and dispersal in the Checker-throated Antwren in Panama. Journal of Avian Biology, Lund, 28: 101-110.

Hinde, R.A. 1956. The biological significance of the territory of birds. The Ibis, London, 98: 340-369.

Juldien, M. \& J-M. Thiollay. 1998. Multi-species territoriality and dynamic of Neotropical forest understory bird flocks. Journal of Animal Ecology, Oxford, 67 (2): 227-252.

Møller, A.P. 1990. Changes in the size of breeding territories in relation to the nestling cycle. Animal Behavior, London, 40: $1070-1079$.

Morse, D.H. 1976. Variables affecting the density and territory size of breeding Spruce-woods warblers. Ecology, Washington, 57 (2): 290-301.

Odum, E.P. \& E.J. Kuenzler. 1955. Measurement of territory size and home range size in birds. The Auk, Lawrence, 72 (2): 128-137.

PARKer, G.A. 1974. Assessment strategy and the evolution of fighting behaviour. Journal of Theoretical Biology, New York, 47 (1): 223-243.

Perrins, C.M. \& T.R. Birkhead. 1983. Avian Ecology. London, Glasgow and Blackie Et Son, 220p.

Ribeiro, B.A., M.F. Goulart \& M.Â. Marini. 2002. Aspectos da territorialidade de Knipolegus lophotes (Tyrannidae, Fluvicolinae) em seu período reprodutivo. Ararajuba, Seropédica, 10 (2): 231-235.

Ridley, R.S. \& G. Tudor. 1994. The Birds of South America: the Suboscine passerines. Austin, University of Texas Press, vol. 2, 814p.

RizzinI, C.T. 1979. Tratado de fitogeografia do Brasil. São Paulo, HUCITEC, 374p.

Robinson, S.K. \& J. Terborgh. 1995. Interspecific aggression and habitat selection by Amazonian birds. Journal of Animal Ecology, Oxford, 64 (1): 1-11.

Rodrigues, M. 1998. No relationship between territory size and the risk of cuckoldry in birds. Animal Behaviour, London, 55: 915-923.

Schoener, T.W. 1968. Sizes of feeding territories among birds. Ecology, Washington, 49 (1): 123-141.

SICK, H. 1997. Ornitologia Brasileira. Uma introdução. Rio de Janeiro, Ed. Nova Fronteira, 862p.

Sieving, K.E. \& J.R. KarR. 1997. Avian extinction and persistence mechanisms in lowland Panama, p. 156-170. In: W.F. LAWREN-
Ce \& R.O. Bierregaard Jr. (Eds). Tropical Forest remmants: ecology, management, and conservation of fragmented communities. Chicago, University Chicago Press, 632p.

Stenger, J. \& J.B. Falls. 1959. The utilized territory of the Ovenbird. The Wilson Bulletin, Ohio, 71 (2): 125-140.

Stotz, D.F.; J.W. FitzPatrick; T. Parker III \& D.K. Moskovits. 1996. Neotropical Birds: Ecology and Conservation. Chicago, University of Chicago Press, 478p.

Stouffer, P.C. 1997. Interspecific aggression in Formicarius antthrushes? The view from central Amazonian Brazil. The Auk, Lawrence, 114 (4): 780-785.

Stutchbury, D.J. \& E.S. Morton. 2001. Behavioral Ecology of Tropical Birds. San Diego, Academic Press, 165p.

Terborgh, J.; S.K. Robinson; T.A. Parker III; C.A. Munn \& N. Pierpont. 1990. Structure and organization of Amazonian Forest bird community. Ecological Monographs, Durhan, 60 (2): 213-238.

Veloso, H.P. 1966. Atlas florestal do Brasil. Rio de Janeiro, Ministério da Agricultura.

VERNER, J. 1977. On the adaptive significance of territoriality. The American Naturalist, Chicago, 111 (980): 769-775.

WikTANDER, U.; O. Olson \& S.G. Nilsson. 2001. Seasonal variation in home-range size, and habitat area requirement of the lesser Spotted Woodpecker (Dendrocopos minor) in southern Swedew. Biological Conservation, Kidlington, 100 (3): 387-395.

Willis, E.O. 1979. The composition of avian communities in remanescent woodlots in southern Brazil. Papéis Avulsos de Zoologia, São Paulo, 33: 1-25.

Willis, E.O. \& Y. Oniki. 1988. Na trilha das formigas carnívoras. Ciência Hoje, Rio de Janeiro, 8 (47): 27-32.

Willis, E.O. \& Y. OniKi. 2001. Birds of a Central São Paulo Woodlot: banded species, p. 69-92. In: J.L.B. Albuquerque; J.F. CÂNDido JR.; F.C. Straube \& A.L. Roos (Eds). Ornitologia e Conservação da Ciência as estratégias. Tubarão, Editora Unisul, 341p.

Woodworth, B.L.; J. FAaborg \& W.J. Arendt. 1999. Survival and longevity of the Puerto Rican Vireo. The Wilson Bulletin, Ohio, 111 (3): 376-380.

Worton, B.J. 1987. A review of models of home range for animal movement. Ecological Modeling, Copenhagen, 38 (34): 277-298.

Wright, J.S. 1979. Competition between insectivorous Lizards and birds in central Panama. American Zoologist, Washington, 19: 1145-1156.

Yamagishi, S. \& K. Ueda. 1986. Simultaneous territory mapping of male Fan-tailed Warblers (Cisticola juncidis). Journal of Field Ornithology, Tulsa, 57 (3): 193-260.

ZAR, J.H. 1984. Biostatistical analysis. New Jersey, PrenticeHall, Engewood Cliffs, $2^{\text {nd }}$ ed., 718p.

Received in 15.IX.2005; accepted in 16.VIII.2006.

Revista Brasileira de Zoologia 23 (3): 692-698, setembro, 2006 